\title{
PHAC SYNTHASES AND PHA DEPOLYMERASES: THE ENZYMES THAT PRODUCE AND DEGRADE PLASTIC
}

\author{
Amro A. AMARA ${ }^{1,2}$ AND HASSAN MOAWAd ${ }^{1,3}$ \\ ${ }^{1}$ Protein Research Department, \\ Genetic Engineering and Biotechnology Research Institute, \\ Mubarak City for Scientific Research and Technological Applications, \\ Alexandria, Egypt. \\ ${ }^{2}$ Microbiology Division, Pharmaceutics Department, King Saud University, \\ Riyadh, Kingdom of Saudi Arabia. \\ ${ }^{3}$ National Research Center, Cairo, Egypt. \\ amroamara@web.de
}

\begin{abstract}
PHAs are a group of intracellular biodegradable polymer produced by (most) bacteria under unbalanced growth conditions. A series of enzymes are involved in different PHAs synthesis, however PhaC synthases are responsible for the polymerization step. PHAs are accumulated in bacterial cells from soluble to insoluble form as storage materials inside the inclusion bodies during unbalanced nutrition or to save organisms from reduces equivalents. PHAs are converted again to soluble components by another pathways and enzymes for the degradation process. PHAs depolymerases are the responsible enzymes. This review is designed to give the non-specialists a condense background about PHAs especially for researcher and students in medicinal and pharmaceutical field.
\end{abstract}

ABSTRAK: PHAs (polyhydroxyalkanoate) merupakan sekumpulan polimer terbiodegradasikan intrasel yang dihasilkan oleh (kebanyakan) bakteria di bawah keadaan tumbesaran tak seimbang. Satu rangkaian enzim terlibat dalam sistesis PHAs yang berbeza, namun sintesis $P h a C$ bertanggungjawab dalam peringkat pempolimeran. PHAs dikumpulkan dalam sel bakteria dari bentuk larut dan tak larut sebagai bahan simpan di dalam jasad terangkum semasa nutrisi tak seimbang atau untuk menyelamatkan organisma daripada pengurangan tak keseimbangan. PHAs ditukarkan sekali lagi kepada komponen larut dengan cara lain dan enzim lain untuk proses degradasi. PHAs depolymerases (enzim yang memangkin penguraian makro molekul kepada molekul yang lebih mudah) merupakan enzim yang bertanggunjawab. Kajian semula ini direka untuk memberi mereka yang bukan pakar, satu ringkasan tentang PHAs terutamanya penyelidik dan penuntut dalam bidang peubatan dan farmaseutikal.

KEYWORDS: polyhydroxyalkanoate; PhaC synthase; PHA depolymerase 


\section{INTRODUCTION}

Perhaps, Beijerinck wrote the first report about lucent granules of PHAs in bacterial cells in 1888 (Reported in Chowdhury, 1963) [1, 2]. Poly- $\beta$-hydroxbutyrate (PHB) was firstly described as an important bacterial product by Lemoigne (1923). Later, Lemoigne (1927) characterized PHB chemically and observed that it was involved in the sporulation of Bacillus spp [3, 4]. Lemoigne and co-workers published 27 articles from 1923 to 1951 [5]. He was the first to observe that these storage materials were not ether soluble, as in lipids. Later, he reported that PHB is the major constituent of these granules. Using microscopic investigation, saponification numbers, and autolysis he proposed a polyester structure with the formula $\left(\mathrm{C}_{4} \mathrm{H}_{6} \mathrm{O}_{2}\right)$ n- and reported that PHB could cast into film like cellulose nitrate material [3-7].

The worldwide demand for degradable plastic is estimated to be 1.4 million metric tons per year by the year 2000, with much of this demand driven by legislation and environmental group [8]. A number of polymers are being developed to meet this demand, with the majority of these being petrochemical based and projected cost at $\$ 6.6 \mathrm{~kg}^{-1}[9,10]$. Natural products being developed as biodegradable plastics include starch blends, polylactic acid, and bacterial polyhydroxyalkanoates (PHAs). PHAs are described as natural polyesters [11]. Copolymers of $\operatorname{poly}(\beta$-hydroxybutyrate-co- $\beta$-hydroxyvalerate) were produced on a large scale by the Imperial Chemical Industries in Billingham, United Kingdom [12, 13]. This copolymer is a thermoplastic which resembles polypropylene [14] and has been successfully test marketed as shampoo bottles in Europe [15]. Although this natural product has great promise, but its high cost is a limiting factor [10]. The large-scale production of bacterial PHA has a number of interesting problems. Major expenses in the production of PHA are determined by the cost of the fermentation substrate, and the extraction of the polymer from inside the cell [12]. Dunolp and Robards (1973) developed the first models for the structure of the inclusion with intriguing observation that this polymer was stretchable even at very low freeze -fracture temperature [16]. PHB was in fact a thermoplastic with properties much like polypropylene [14]. It was shown that PHB copolymers that contained an amount of $\beta$-hydroxyvalerate and designated $\mathrm{P}(\mathrm{HB}-\mathrm{co}-\mathrm{HV})$ could be formed by co-substrate feeding [17]. 3-Hydroxyvalerate synthesis is dependent on the presence of both glucose and propionate [18]. For PHAs nomenclature and abbreviation refer to Amara [2]. Many years have been lost after the first bulk interest with this polymer shown by Lemoigne and his group. However, minor researches have been made. Weibull had isolated the granules of Bacillus megaterium by dissolution of the cell wall with a lysozyme [21]. Doudoroff and Stanier and Stainer et al. found that PHB can be produced by photosynthetic assimilation of organic compounds by phototrophic bacteria [21, 22]. They described that the reaction involved in the metabolic pathway is responsible for the biosynthesis of PHB from acetic acid [22, 23]. Lusty and Doudoroff have shown a study on depolymerases, which were able to hydrolyze PHB [24]. Schlegal observed that Cupriavidus necator (formally Wautersia eutropha, Ralstonia eutropha and Alcaligenes eutrophus), could accumulate very large amount of PHB in a media with low nitrogen content [25]. The most challenging work on PHAs started when Schlegal working with $C$. necator and Dawes working with Azotobacter berjerinckii succeeded to isolate and characterize the enzymes catalyse the PHB monomer synthesis [26, 27]. Isolating 
the PhaC synthases was the real step to facilitate the cloning of their responsible genes. The PHA synthase operon of $C$. necator were cloned in three labs nearly in a short span of time [28-30]. Wallen and Rohwedder reported heteropolymers of HB and 3-hydroxyvalerate in chloroform extracts of activated sewage sludge as major constituents with C6 and possibly C7 3-hydroxyacids as minor components [31]. De Smet et al. characterized $\mathrm{PHA}_{\mathrm{MCL}}$ in Pseudomonas oleovorans during growth on octane [32]. Huisman et al. proved that $\mathrm{PHA}_{\mathrm{MCL}}$ accumulation was the common criteria of fluorescent pseudomonads [33]. PHAs are also produced by gram positive, negative and phototrophic bacteria as well as archaea [34-39].

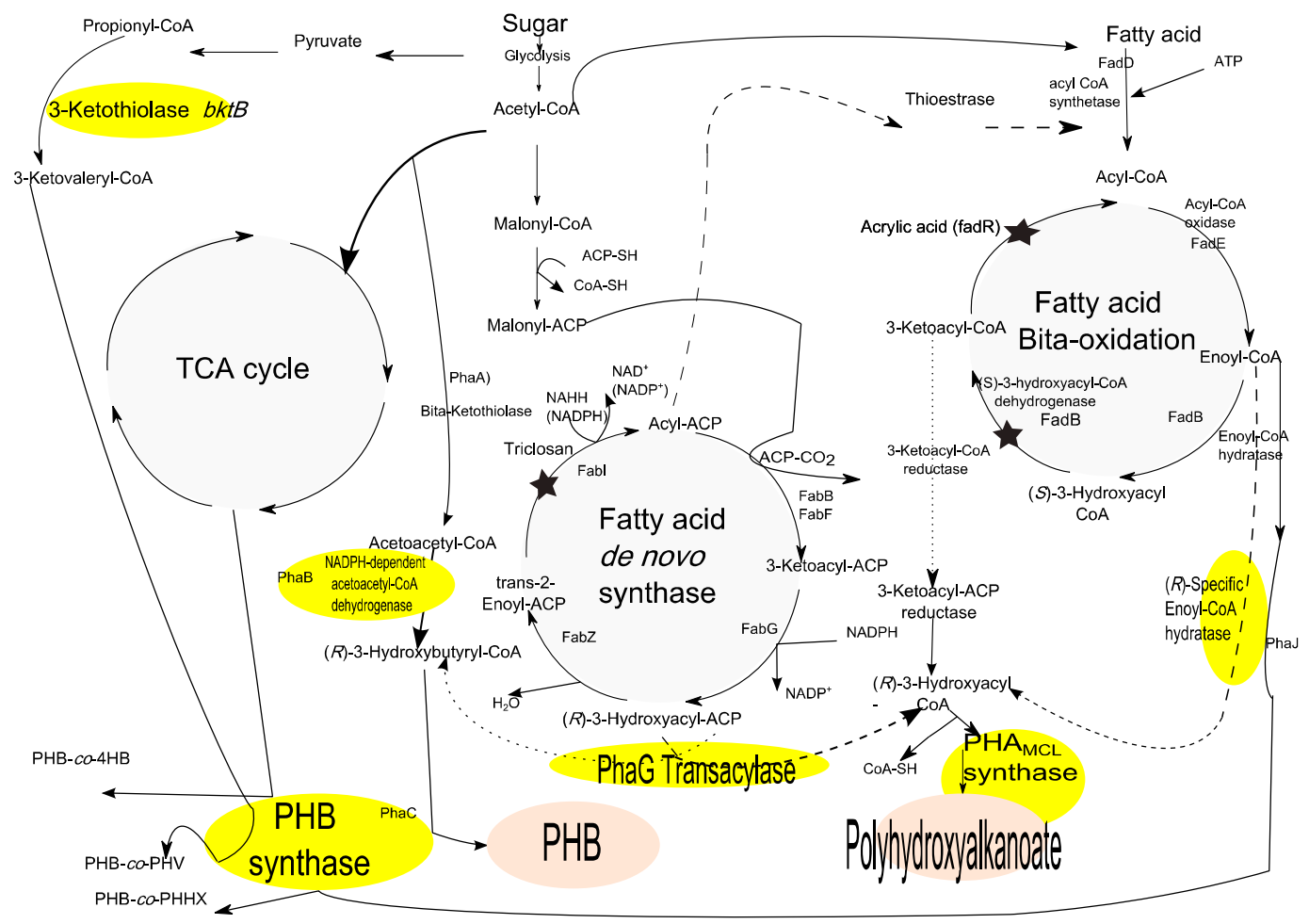

Fig. 1: PHAs metabolic different pathways (modified after Amara [2, 19]).

\section{PHAs PRODUCTION}

Examination of the enzymes leading to the formation of PHB has shown that the regulation of PHB synthesis is controlled by acetyl-Co-enzymes A (CoA) acyltransferase [26, 40 , 41]. Under balanced growth conditions, acetyl-CoA is fed into the tricarboxylic acid cycle and the resultant CoA inhibits acety-CoA acyltransferase and PHB synthesis. Under nutrient limitation (e.g., oxygen limitation) and carbon excess, NADH oxidase activity decrease, $\mathrm{NADH}$ increase and inhibits citrate synthase and isocitrate dehydrogenase, and acety-CoA 
acyltransferase by $\mathrm{CoA}$ is overcome. The ensuing condensation reaction forms acetoacetylCoA and initiates PHB synthesis [26, 40]. The high NADH/NAD ratio caused oxygen limitation rapidly readjusts as PHB synthesis starts, and PHB assumes the role of an alternative electron acceptor [40]. The polymer is normally accumulated in response to the limitation of an essential nutrient and much of the past work has concerned the control of the synthesis of PHB under in-balanced growth condition [26, 41]. PHB is the most broadly studied PHAs. The PHB biosynthesis pathway consists of three distinct enzymatic reactions, as depicted in Fig. 1. The regulation of PHB synthesis is controlled by acetyl-coenzymes A (CoA) acyltransferase [40, 42]. The first reaction comprises the condensation of two acetyl coenzyme A (acetyl-CoA) molecules into acetoacetyl-CoA by $\beta$-ketoacyl-CoA thiolase $(\beta$ ketothiolase) (encoded by phaA). The second reaction is the reduction of acetoactyl-CoA to $(R)$-3-hydroxybutyryl-CoA by an NADPH-dependent acetoacetyl-CoA dehydrogenase (encoded by $p h a B$ ). Finally, the $(R)-3$-hydroxybutyryl-CoA monomers are polymerized to $\mathrm{P}(3 \mathrm{HB})$ by $\mathrm{P}(3 \mathrm{HB})$ synthase (encoded by phaC). Synthesis of $\mathrm{PHB}$ is believed to be controlled by the first enzyme, 3-ketothiolase that is inhibited by coenzyme A (CoASH). Synthesis of PHAs other than $\mathrm{P}(3 \mathrm{HB})$ which are not related to their growth substrates occurs relatively rare in nature [42]. Antonio et al. and Amara et al. produced 3HB-3HHX from cultivation of recombinant E. coli on fatty acid using PhaC class I and acrylic acid [44, 45]. 4hydroxybutyrate (4HB) was produced in recombinant E. coli using succinyl-CoA from the citric acid cycle, which is converted to 4-hydroxybutyryl-CoA, a precursor for PHA biosynthesis [46].

Sixty years after the discovery of PHB, De Smet described the accumulation of the $\mathrm{PHA}_{\mathrm{MCL}}$ in Pseudomonas oleovorans grown on octane as sole carbon source [32]. PHA from pseudomonads rRNA homology group I were directly related to the structure of the alkane, alkene or fatty acid they used as carbon source [33, 47]. These substrates called 'related substrates'. When the carbon source consists of fatty acids with 6 to 12 carbon atoms, monomers of the PHA are of the same length as the carbon source or are shortened by 2, 4 or 6 carbon atoms. Pseudomonads are able to produce PHA $_{\mathrm{MCL}}$ from sugar. These substrates, which do not resemble the monomers of the accumulated polymer, are named "unrelated substrates". Pseudomonads of the rRNA homology group I like Psudomonas putida KT2442, accumulate PHA that consists primarily of $\mathrm{C} 10$ and $\mathrm{C} 8$ monomers, when grown on sugars or gluconate $[48,49]$. Experimental evidence suggests that these monomers are derived from intermediates of fatty acid biosynthesis and that the composition of the PHAs is most likely a reflection of the pool of fatty acid biosynthetic intermediates. Reush describes native low molecular mass PHB in yeast and many other eukaryotic cells [50].

Expression of the $C$. necator PHB biosynthetic pathway was successfully achieved in the yeast Saccharomyces cerevisiae by Leaf et al. [51]. He reported that the expression of PHB synthase in the yeast cytoplasm is sufficient for PHB accumulation and that wild type yeast synthesis D-3HB-CoA could raise from intermediates in fatty acid synthesis or through $\beta$ oxidation [51]. Yeast cells can be used as models to gain information about PHAs synthesis in eukaryotes [52]. It is confirmed that three thiolases exist in S. cerevisiae functioning in mitochdria, cytoplasm and peroxisomes [53, 54]. Safake et al. in their study succeeded to 
isolate PHB producing wild type yeast strain from Kombucha tea and reported that the amount of PHB is less than that from prokaryotic and the PHB amount depend upon the type of culture and species [55]. Simple strategy for biosynthesis of polyhydroxyalkanotes in wild type yeasts has been described [56]. Synthesis of PHA SCL $_{\text {was }}$ established in the peroxisome of a wild-type yeast strain by targeting the $C$. necator SCL polymerase to the peroxisome [57]. Other strategies for using yeasts other than $S$. cerevisiae have been reported [58, 59]. Plants are able to produce PHAs directly from $\mathrm{CO}_{2}$ and solar energy after being transgenic [50]. Steinbüchel and Füchtenbusch reported that the costs of the production of PHAs in transgenic plants could be of the same order of magnitude of their substrate costs (eg. sucrose, lipids and starch), if all the prerequisites are met [60]. PHB has been produced in transgenic Arabidopsis thaliana [61], Brassica napus [62], Gossypium hirsutum [63], Nicotiana tabacum [64] and Zea mays [52]. The copolyester PHB-co-PHV [65] and PHAs consisting of 3HA [66] have been produced too. Recently Petrasovits et al. succeeded to produce of polyhydroxybutyrate in sugarcane [67].

\section{CLASSES OF PHA SYNTHASES}

PHA synthases were classified into four classes based on their substrate specificity and subunit composition. The multiple alignment of the primary structures of these PHA synthases show an overall identity with few conserved amino acids residues (Fig. 2). However, each synthase from the same class is clustered in one group as in Fig. 3. General model for each class can be performed as illustrated in Fig. 4. Only class IV is clustered with class III while class III is so close to it. Class I PHA synthases, with $C$. necator synthase as prototype, are composed of one single type of polypeptide chain and use mainly $(R)-3$ hydroxybutyryl-CoA, $(R)$-3-hydroxyvaleryl-CoA and other short-carbon chain length hydroxyalkanoic acid CoA thioesters including 3-mercaptoalkanoic acid CoA thioesters as substrates [68, 69]. Class III PHA synthases, as represented by the Allochromatium vinosum enzyme, are composed of two different subunits each of about $40 \mathrm{kDa}$ [70]. The substrate specificity of class III is similar to that of class I synthases, although some MCL 3hydroxyfatty acids are also incorporated [71]. Class II enzymes as well as class I PHA synthases are composed of only one type of subunit. Class I and II were purified, and there in vitro activities have been determined [72-74]. Class II mainly found in pseudomonades such as $P$. aeruginosa. One major difference between class II and both of class I and III, PHA synthases is the substrate specificity.

Class II PHA synthases incorporate preferentially 3-hydroxyfatty acids of MCL (C6C14) into PHAs, and the resulting product is a latex-like polymer [74-76]. These substrates are mainly derived from intermediates of fatty acid $\beta$-oxidation or from fatty acid de novo biosynthesis provided fatty acids or simple non-related carbon sources [78, 80-83]. Class II PHA synthases were purified and in vitro activity was determined [83, 84]. A threading model of the A. vinosum PHA synthase was generated [85]. Accordingly, a threading model of the class II PHA synthase from $P$. aeruginosa was developed with the aid of the SAMT98 algorithm and based on the homology to the structure of the lipase from B. cepacia [86]. 
Amara and Rhem reported that $\mathrm{H} 479$ is not the general base catalyst that activates the nucleophilic $\mathrm{C} 296$ for covalent catalysis and that $\mathrm{H} 452$ plays a major role [87]. In the multiple alignment of PHA synthases only one cysteine residue (Cys-319) is highly conserved. Therefore, scientists have been searching for several years for the second thiol group. The essential role of Cys-319 of the C. necator PHA synthase (Class I) for the reaction mechanism was obtained from site specific mutagenesis [72]. The weakly conserved Cys-459 was supposed to be involved in the catalytic cycle, providing the second thiol group. However, site specific mutagenesis [72] clearly indicated that this amino acid residue is not essential for catalytic activity. In position 260 of the PHA synthase from C. necator a conserved serine residue was observed. Ser-260 was proposed as target for covalent posttranslational modification by 4-phosphopantetheine, which should provide the second thiol group similar to fatty acid synthase. In order to investigate posttranslational modification by 4phosphopantetheine, radiolabeling experiments were conducted, expressing PHA synthase gene from $C$. necator in E. coli SJ16 (panD). Since E. coli SJ16 is $\beta$-alanine auxotroph, specific radiolabeling of 4-phosphopantetheinylated proteins occurs, when cells were fed with $2^{-14} \mathrm{C}-\beta$-alanine. These experiments indicated that the PHA synthase was labeled by $4-$ phosphopantetheine [72]. However, detailed analysis revealed that only a small portion of total PHA synthase was labeled [88]. Functional low level expression of PHA synthases from $C$. necator and P. aeruginosa, respectively, in E. coli SJ16 and also in $\beta$-alanine auxotrophic mutants of $C$. necator with subsequent analysis of 4-phosphopantetheinylated proteins gave no evidence for covalent posttranslational modification by 4-phosphopantetheine [89]. Exchange of amino acid residue Ser-260 against alanine and threonine, respectively, abolished in vivo and in vitro activity of PHA synthase from C. necator [89]. The model of active PHA synthase involves two subunits forming a homodimer considering class I and II PHA synthases, and forming a heterodimer (PhaC and PhaE) in case of class III PHA synthases. Accordingly, class I and II PHA synthases possess two thiol groups provided by conserved Cys-319, and in class III PHA synthases the second thiol group might be provided by conserved Cys-130 of subunit PhaE from A. vinosum [88]. A novel PHA synthase (class V) from Bacillus megaterium required $\mathrm{PhaC}_{B m}$ and $\mathrm{PhaR}_{B m}$ for activity in vivo and in vitro was reported [90]. PhaC $C_{B m}$ showed greatest similarity to the PhaCs of class III in both size and sequence (Figure 3,4). Unlike those in class III, the $40 \mathrm{kDa}$ PhaE was not required, and furthermore, the $22 \mathrm{kDa} \mathrm{PhaR}_{B m}$ had no homology to PhaE.

\section{PHAS BIODEGRADATION}

Lusty and Doudoroff reported the presence of depolymerase activities in Pseudomonas lemoignei ans was able to degrade PHB [24]. While depolymerases have been studied for about 45 years, the first structural gene of a PHA depolymerase (Alcaliginus faecalis, pha $Z_{A f}$ ) was cloned and sequenced only in 1989 by Saito et al [91]. Depolymerases are highly specific for the polymers consisting of monomers in the $(R)$ configuration [92]. PHAs depolymerase are carboxyesterases (EC 3.1.1) and hydrolyze the water insoluble polymer to water-soluble monomers and /or oligomers and lastly to water and carbon dioxide or methane. Early PHB degrading bacteria were isolated by selection for microorganisms able to utilize PHB as the 
sole source of carbon and energy [1, 2]. PHAs degrading bacteria differ from each other depending on the type of PHAs they degrade, however some bacteria revealed a rather broad polyester specificity and are able to utilize a wide range of PHAs [93, 94]. Three intracellular PHA depolymerases (PhaZ1, PhaZ2 and PhaZ3) and a 3HB-oligomer hydrolase (previously designated PhaZ2), which hydrolyse PHAs and the cleavage products produced by PhaZs, were cloned and characterized in C. necator [94-97]. Molds also could degrade PHAs and their depolymerases have been characterized $[98,99]$. PHAs depolymerases show a similar characteristic, they are stable at a range of $\mathrm{pH}$, temperature, relatively small $\mathrm{Mr}(<70 \mathrm{KDa})$, they are inhibited by reducing agent, e.g. dithioerythritol (DTT), which indicates the presence of essential disulfide bonds, and by serine hydrolase disulfide bonds, and serine hydrolase inhibitors such as diisopropyl-fluorylphosphate (DFP) or acylsulfonyl derivatives [99]. 

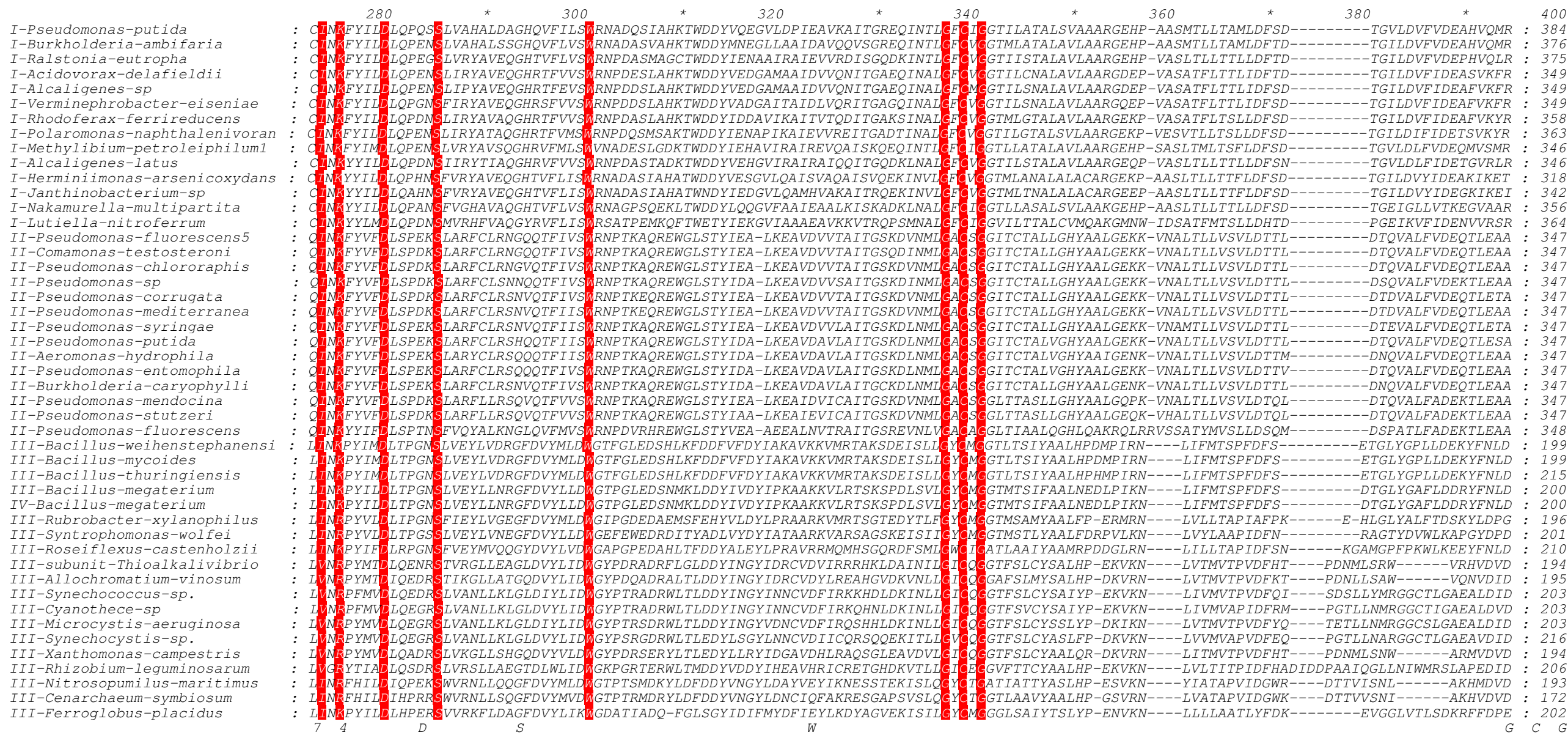

Fig. 2: Part of the multiple amino acids alignment of different PhaC synthases, shaded lines show different conserved regions. 


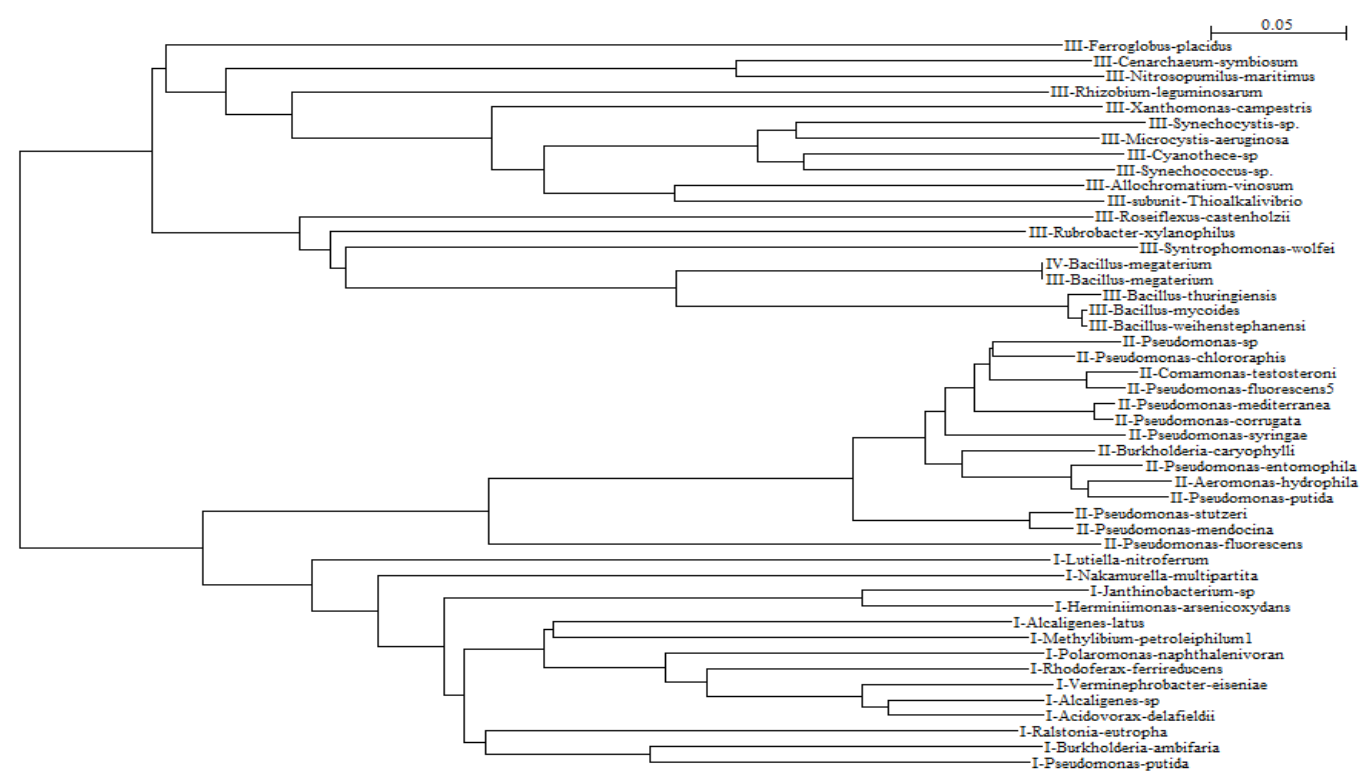

Fig. 3: Phylogenic tree for Class I, II, III and IV PhaC synthases.
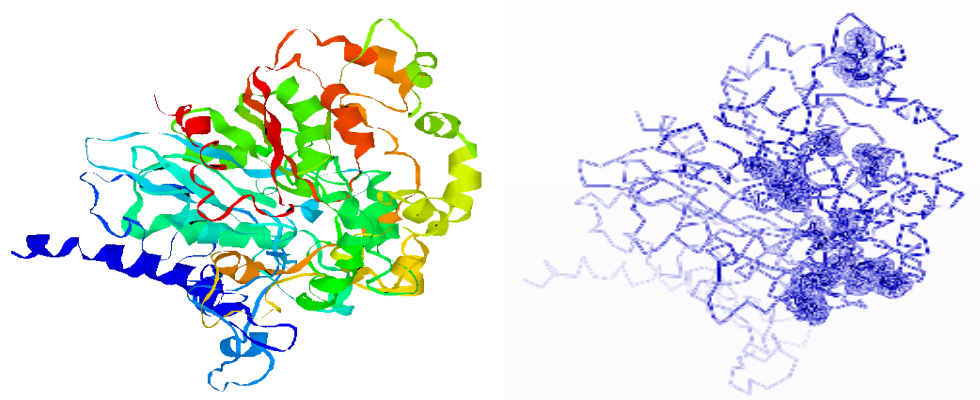

Fig. 4: PhaC synthase Class I model (left) and its conserved amino acids (right).

Depolymerases have three strictly conserved amino acids: serine, aspartate and histidine. The serine is part of the lipase-box pentapeptide Gly-Xaa1-Ser-Xaa2-Gly [100]. The oxygen atom of the serine side chain is the nucleophile that attacks the ester bond [93]. Many strategies were describing using depolymerases in the biotechnological products using efficient microbial strains $[19,101,102]$. Ihssen et al. show a study for using extracellular $\mathrm{PHA}_{\mathrm{MCL}}$ depolymerase for targeted binding of proteins to artificial Poly[(3-hydroxyoctanoate)-co-(3-hydroxyhexanoate)] granules [103].

\section{PROTEIN ENGINEERING OF PHAC SYNTHASE}

Tha PhaC synthases show a great homology (as in Fig. 2) to each other and the conserved amino acids have been highlighted (Fig. 2). Aiming to change the PhaC substrate specificity, improve their activities', determine their active sites' and discover new futures, different tools of genetic and protein engineering tools have been implemented to the genes encoded different PhaC synthases [2]. Aiming to enhance the PhaC synthase activity Amara et al. establish a protocol for in vivo random mutagenesis of 
the pha $C_{A p}$ (Aeromonac punctata) [44, 45]. Four mutants exhibited enhanced in vivo and in vitro PHA synthase activity. The in vitro activities of the overproducing mutants ranged from 1.1 to 5-fold of the wild type activity, whereas the amounts of accumulated PHA ranged from 107\%-126\% to that of the wild type [44, 45]. A list of mutants and their site in the $p h a C_{C n}$ have been described in details by Rehm et al. and their related effect on $\mathrm{PhaC}_{C n}$ structure/activity have been discussed [86]. An attractive observation (in the work done by Amara et al. was the increase in weight average molecular mass of the PHA synthesized by the modified PHA synthase, which suggest a higher processivity of the enzymes with less frequently occurring chain transfer reactions $[44,45]$. Slight preference of $\mathrm{C} 4$ over $\mathrm{C} 6$ was observed in the mutants as compared to the wild-type which keep the door open for the possibility of changing the substrate specificity [44, 45].

Taguchi et al. have been used another strategy based on in vitro mutagenesis for $p h a C_{C n}$ using PCR $[105,106]$. Seven site directed mutations have been performed in $\mathrm{PhaC}_{P a}$ where five conserved residues were replaced by site directed mutagenesis in order to identify the function of these amino acids in catalysis. The substitution of W398 by alanine abolished $\mathrm{PHA}_{\mathrm{MCL}}$ synthase activity indicating that W398 is essential for enzyme activity [87]. The substitution of $\mathrm{H} 479$ by glutamine did not affect the $\mathrm{PHA}_{\mathrm{MCL}}$ activity, which indicates that $\mathrm{H} 479$ is not the general base catalyst that activates the nucleophilic C296 for covalent catalysis. The substitution of C296 with serine, which is the general base catalyst in lipases, did not abolish $\mathrm{PHA}_{\mathrm{MCL}}$ synthase activity while still exhibiting $20 \%$ activity in comparison to the wild type. Substitution of C296 with alanine abolished PHA $_{M C L}$ synthase activity which is a strong evidence that serine may be able to replace cysteine as catalytic nucleophile for changing substrate specificity of PHA synthase. For further investigation, another site directed mutagenesis has been done in another conserved histidine (H452), which was replaced with glutamine. The H452Q mutant was highly impaired in $\mathrm{PHA}_{\mathrm{MCL}}$ activity, which indicates that $\mathrm{H} 452$ plays a major role as a general base catalyst instead of H479 [87]. Hu et al. (2007) reported an improve for fractions by using site directed mutagenesis. The recombinant E. coli harboring plasmid pETJ1 (L65A), pETJ2 (L65V) or plasmid pETJ3 (V130A) synthesized the enhanced $3 \mathrm{HHx}$ fractions of PHBHHx from dodecanoate, indicating that Leu-65 and Val-130 of PhaJ(Ah) play an important role in determining the acyl chain length substrate specificity. The mutated PhaJ (Ah) (L65A, L65V, or V130A) provided higher 3HHx precursors for PHA synthase, resulting in the enhanced 3HHx fractions of PHB-co-HHx [107]. Fusion proteins composed of the $\mathrm{N}$ terminal part of the PHA synthase from $P$. aeruginosa and the $\mathrm{C}$ terminal part of the PHA synthase from $C$. necator indicated that fusion points located in the $\alpha / \beta$-hydrolase fold region are not tolerated. Furthermore, these fusion points were located in predicted and structurally conserved $\alpha$-helical regions [104].

Matsumoto et al. reported a chimeric enzyme composed of polyhydroxyalkanoate (PHA) synthases from $C$. necator and Aeromonas caviae enhances production of PHAs in recombinant E. coli. [107]. An $P$. putida mutant was isolated which is able to grow

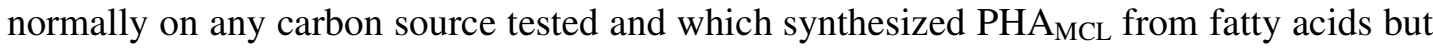
not from gluconate or glucose [78]. Biochemical studies on the affected enzyme revealed that this enzyme catalyses the transfer of $(R)$-3-hydroxydecanoyl moieties from the acyl carrier protein: coenzyme A transferase. The respective gene, which complemented the mutant, was referred to as $p h a G$ [78]. which has been also identified and cloned from $P$. aeruginosa [81] and P. oleovorans [82]. The PhaG protein overproduced in E. coli as a Cterminal $\mathrm{His}_{6}$-tagged fusion protein. The $\mathrm{His}_{6 \mathrm{x}}$-tagged $\mathrm{PhaG}$ was purified to homogeneity by refolding of PhaG obtained from inclusion bodies, and a new enzyme assay was established. Gel filtration chromatography analysis in combination with light scattering 
analysis indicated substrate-induced dimerization of the transacylase. In the presence of the substrate $(R)$-3-hydroxyacyl-CoA the transacylase appeared in apparent molecular weights of $45.4,83.7$ and $102 \mathrm{kDa}$, which indicated substrate-induced conformational changes and oligomerization of the transacylase [108]. A threading model of PhaG was developed based on the homology to an epoxide hydrolase (1cqz). In addition, the alignment with the $\alpha / \beta$-hydrolase fold region indicated that PhaG belongs to $\alpha / \beta$-hydrolase superfamily [108]. Accordingly, CD analysis suggested a secondary structure composition of $29 \% \alpha$-helix, $22 \% \beta$-sheet, $18 \% \beta$-turn and $31 \%$ random coil that support the PhaG protein model. Using hanging drop methods Amara, (2003) obtain crystals from the purified PhaG [20]. PhaG is responsible for diverting intermediates of fatty acids to PhaC synthase to produce new polymers of $\mathrm{PHA}$ SCL/MCL.

\section{ACKNOWLEDGMENT}

The corresponding author would like deeply to acknowledge Ms Siham Zayer for advices during writing this review.

\section{REFERENCES}

[1] A Chowdhury "Poly- $\beta$-hydroybuttersäure abbauende Bakterien und Exoenzyme". Arch. Mikrobiol. vol. 47 pp. 167-200, 1963.

[2] AA Amara "Polyhydroyalkanoates: from Basic Research and Molecular Biology to Application". IIUM Engineering Journal, vol. 9 (1): pp. 37-73, 2008.

[3] M Lemoigne "Production d'acide $\beta$-oxybutyrique par certaines bact'eries du groupe du Bacillus subtilis". C.R. Hebd. Seances Acad. Sci., vol. 176 pp. 1761, 1923.

[4] M Lemoigne "Etudes sur l'autolyse microbienne. Origine de l'acide $\beta$-oxybutyrique form'e par autolyse". Ann. Inst. Pasteur (Paris). vol. 39 pp. 144, 1927.

[5] RD de la Rivie`re "Notice Ne'crologique sur M. Maurice Lemoigne (1883-1967) " C. $R$. Acad. des Sci., Paris, t. vol. 264, 1967.

[6] M Lemoigne "Etudes sur l'autolyse microbie acidification par formation d'acide $\beta$ oxybutyrique, Ann. Inst. Pasteur., vol. 39 pp. 144, 1925.

[7] M Lemoigne "Produits de l'hydration et de polymerisation de l'acide $\beta$-oxobutyrique". Bull. Soc. Chem. Biol. (Paris), vol. 8 pp. 770-782, 1926.

[8] R Leaversueh "Industry weighs the need to make polymer degradable". Mod. Plastics vol. 64(8) pp. 52-55, 1987.

[9] KF Lindsay, ""Truly degradable" resins are now truly commercial". Mod. Plastics, vol. 69(2) pp. 62-64, 1992.

[10] JW Moore "Degradable plastics. Mod. Plastics 69(13) pp. 58-63, 1992.

[11] AJ Anderson, GW Haywood, and EA Dawes "Biosynthesis and composition of bacterial poly (hydroxyalkanoates) ". Int. J. Biol Macromol. 12 pp. 102-105, 1990.

[12] D Byrom "Polymer synthesis by microorganisms: technology and economics". Trends Biotechnol. vol. 5 pp. 246-250. 1987.

[13] WD Luzier "Materials derivedbiomas/biodegradable materials". Proc. Natl. Acad. Sci. USA, vol. 89 pp. 839-842, 1992.

[14] PP King "Biotechnology. An industrial view. J. Chem. Tech. Biotechnol. vol. 32 pp. 2-8, 1982.

[15] D. Rotman "Monsanto takes a chance on Zeneca's Biopol Technology". Chemical Week, vol.158 pp. 21.1996 ,

[16] WF Dunlop and AW Robards "Ultrastructural sudy of poly- $\beta$-hydroxybutyrate granules from Bacillus cereus". J. Bacteriol. vol. 114 pp. 1271-1280, 1973.

[17] PA Holmes, LF Wright and SH Collins "Eur.Pat.Appl.0 052 459, 1981. 
[18] SC Slater "Production of Poly-(3-Hydroxybutyrate-Co-3-Hydroxyvalerate) in a Recombinant Escherichia coli Strain". J. Applied and Environmental Microbiology, vol. 58 pp. 1089-1094, 1992.

[19] AA Amara "From Gene to plastic: From phaC synthase to Polyhydroxyalkanoates". Ed Amara AA. Schüling Verlag Germany, 2010.

[20] AA Amara "Biochemical and Molecular Characterization of PHA synthases from Pseudomonas aeruginosa, Ralstonia eutropha, Aeromonas punctata as well as of the (R)-3hydroxyacyl-ACP:CoA transacylase from Pseudomonas putida". Ph. D. Thesis: ISBN: 3930962039-Germany, 2003.

[21] C Weibull "Characterization of the protoplasmic constituents of Bacillus megaterium". J. Bacteriol, vol. 66(6) pp. 696-702, 1953.

[22] M Doudoroff and RY Stanier "Role of poly- $\beta$-hydroxybutyric acid in the assimilation of organic carbon by bacteria". Nature. vol. 183 pp. 1440, 1959.

[23] RY Stanier, M Doudoroff, R Kunisawa and R Contopoulou "The role of organic substrates in bacterial photosynthesis". Proc. Natl. Acad. Sci. U S A, Aug; vol. 45(8) pp. 1246-1260, 1959.

[24] CJ Lusty and M Doudoroff "Poly- $\beta$-hydroxybutyrate depolymerases of Pseudomonas lemoignei". Biochemistry, vol. 56 pp. 960-965, 1966.

[25] HG Schlegel, H Kaltwasser and G Gottschalk "[A submersion method for culture of hydrogen-oxidizing bacteria: growth physiological studies.] ". [Article in German] Arch. Mikrobiol., vol. 38 pp. 209-222, 1961.

[26] V Oeding and HG Schegel " $\beta$-Ketothiolase from Hydrogenomonas eutropha H16 and its significance in the regulation of poly- $\beta$-hydroxybutyrate metabolism". Biochem. J,. vol. 134 pp. 239-248, 1973.

[27] PJ Senior and EA Dawes "The regulation of the poly- $\beta$-hydroxybutyrate metabolism in Azotobacter beijerinckii". Biochem. J., vol. 134 pp. 225-238, 1973.

[28] A Schubert, A Steinbuchel. and HG Schlegel. "Cloning of the Alcaligenes eutrophus genes for synthesis of poly-beta-hydroxybutyric acid (PHB) and synthesis of PHB in Escherichia coli". J. Bacteriol., vol. 170(12) pp. 5837-5847, 1988.

[29] SC Slater WH Voige and DE Dennis "Cloning and expression in Escherichia coli of the Alcaligenes eutrophus H16 poly- $\beta$-hydroxybutyrate biosynthetic pathway". J. Bacteriol., vol. 170 pp. 4431-4436, 1988.

[30] OP Peoples and AJ Sinskey "Poly- $\beta$-hydroxybutyrate (PHB) biosynthesis in Alcaligenes eutrophus H16. Identification and characterization of the PHB polymerase gene ( $p h b C)$ ". J. Biol. Chem., vol. 264 pp. 15298-15303, 1989.

[31] LL Wallen and WK Rohwedder. "Poly- $\beta$-hydroxy-alkanoate from activated sludge". Environ. Sci. Technol, vol. 8 pp. 576- 579, 1974.

[32] MJ De Smet, G Eggink, BB Withold, J Kingma and H Wynberg "Characterization of intracellular inclusions formed by Pseudomonas oleovorans during growth on octane". J. Biotechnol. vol. 154 pp. 870-878, 1983.

[33] GW Huisman, O de Leeuw, G Eggink and B Witholt "Synthesis of poly-hydroxyalkanoates is a common feature of fluoresent pseudomonads". Appl. Environ. Microbiol., vol. 55 pp. 1949-1954, 1989.

[34] R Fernandez-Castillo, F Rodrigues-Valera, J Gonzalez-Ramos and F Ruiz-Berraquero "Accumulation of poly( $\beta$-hydoxybutyrate) by halobacteria". Appl. Environ. Microbiol. vol. 51 pp. 214-216, 1986.

[35] AJ Anderson and EA Dawes "Occurrence, metabolism, metabolic role, and industrial uses of bacterial polyhydroxyalkanoates". Microbiol. Rev. vol. 54 pp. 450-472, 1990.

[36] A Steinbüchel "Polyhydroxyalkanoic acids. In: Byrom D (ed) Biomaterials: novel materials from biological sources". Stockton, New York, 124-213, 1991.

[37] Steinbüchel A, B Füchtenbusch, V Gorenflo, S Hein, R Jossek, S Langenbach and BHA Rehm "Biosynthesis of polyesters in bacteria and recombinant organisms". Polym. Degrad. Stab. vol. 59 pp. 177-182, 1997. 
[38] A Steinbüchel and S Hein "Biochemical and molecular basis of polyhydroxyalkanoic acids in microorganism", in Biopolyester, A. Steinbuchel, Babel, W., (Eds), Adv. Biochem. Eng. Biotechnol., vol. 71 81-123, 2001.

[39] MS Shabeb, M Younis, AA Amara and A Shoreit "Production of PHB-co-PHV from Compost Bioremediation by Purple non-sulfur bacteria". Egyptian. J. Biotechnol. vol. 19 pp. 467-478, 2005.

[40] FA Jackson, and EA Dawes "Regulabon of the tricarboxylic acid cycle and poly-bhydoxybutyrate metabolism in Azotobacter beijerinckii grown under nitrigen or oxygen limitation". J. Gen. Microbiol., vol. 97 pp. 303-312, 1976.

[41] PJ Senior and EA Dowses "Poly-b-hydroxybutytate biosynthesis and the regulation of glucose metabolism in Azotobacter beijerinckii". Biochem. J. vol. 125 pp. 55-66, 1971.

[42] Y Asada, M Miyake, J Miyake, R Kurane and Y Tokiwa "Photosynthetic accumulation of poly-(hydroxybutyrate) by cyanobacteria-the metabolism and potential for $\mathrm{CO}_{2}$ recycling". Int. J. Biol. Macromol. vol. 25(1-3) pp. 37-42, 1999.

[43] RV Antonio, A Steinbüchel and BHA Rehm "Analysis of in vivo substrate specificity of the PHA synthase from C. necator: formation of novel copolyester in recombinant Escherichia coli". FEMS Microbiol. Lett. 182 pp. 111-117, 2000.

[44] AA Amara, BHA Rehm and A Steinbüchel "Biopolymer overproduction by new mutants using simple methods for selection". In DAAD-Bioforum-Berlin 'Grenzenlos forschen", DAAD, Biotechnologische Methoden. vol. 231-239, 2001.

[45] AA Amara, A Steinbüchel and BHA Rehm "In vivo evolution of the Aeromonas punctata polyhydroxyalkanoate (PHA) synthase $\mathrm{pp}$. Isolation and characterization of modified PHA synthases with enhanced activity". Appl. Microbiol. Biotechnol. 59 pp. 477-482, 2002.

[46] HE Valentin, and D Dennis "Production of poly (3-hydroxybutyrate-co-4-hydroxybutyrate) in recombinant Escherichia coli grown on glucose". J. Biotechnol. vol. 58 pp. 33-38, 1997.

[47] H Brandl, RA Gross, RW Lenz and RC Fuller "Pseudomonas oleovorans as a source of poly( $\beta$-hydroxyalkanoates) for potential applications as biodegradable polyesters". Appl. Environ. Microbiol. vol. 54 pp. 1977-1982, 1988.

[48] A Timm and A Steinbüchel "Cloning and molecular analysis of the poly(3-hydroxyalkanoic acid) gene locus of Pseudomonas aeruginosa PAO1". Eur. J. Biochem., vol. 209 pp. 15-30, 1992.

[49] GNM Huijberts, G Eggink, P de Waard, GW Huisman and B Witholt "Pseudomonas putida KT2442 cultivated on glucose accumulates poly(3-hydroxyalkanoates) consisting of saturated and unsaturated monomers". Appl. Environ. Microbiol., vol. 58 pp. 536-544, 1992.

[50] RN Reush "Poly- $\beta$-hydroxybuyrate/calcium Polyhydroxyphosphate, a biodegradable thermoplastic produced in transgenic plants". Science, vol. 256 pp. 520-523, 1989.

[51] TA Leaf, Peterson MS, Stoup SK, Somers D and Srienc F "Saccharomyces cerevisiae expressing bacterial polyhydroxybutyrate synthase produces poly-3-hydroxybutyrate". Microbiology vol. 142 pp. 1169-1180, 1996.

[52] JJ Hahn, AC Eschenlauer, MH Narrol, DA Somers and F Srienc "Growth kinetics, nutrient uptake, and expression of the Alcaligenes eutrophus poly( $\beta$-hydroxybutyrate) synthesis pathway in transgenic maize cell suspension cultures". Biotechnol. Prog., vol. 13 pp. 347354, 1997.

[53] JA Kornblatt, and H Rundney "Two forms of acetoacetyl coenzyme A thiolase in yeast II. Intracellular location and relationship to growth". J. Biol. Chem., vol. 246 pp. 4424-4430, 1971.

[54] JC Igual, C Gonzalez-Bosch, and JE Perez-Ortin "The POTL* gene for yeast peroxisomal thiolase is subject to there different mechanisms of regulation". Mol. Microbiol., vol. $6 \mathrm{pp}$. 1867-1875, 1992.

[55] S Safak, N Mercan, B Aslim and Y Beyatli "A study on the production of Poly-BetaHydroxybutyrate by some eukyryotic microorganisms". Turkish Electronic Journal of Biotechnology, pp. 11-17, 2002. 
[56] DAM Abd-El-haleem, SA Zaki, AT Abuelhamd, AA Amara, , Abuelreesh G."Biosynthesis of polyhydroxyalkanotes in wild type yeasts". J. Appl. Sci. Environ. Manage. vol. 11(3): pp. $5-10,2007$.

[57] $\mathrm{B}$ Zhang, $\mathrm{R}$ Carlson and $\mathrm{F}$ Srienc "Engineering the monomer composition of polyhydroxyalkanoates synthesized in Saccharomyces cerevisiae". Appl. Environ. Microbiol., vol. 72(1) pp. 536-543, 2006.

[58] T A Abuelhamd DAM Abd-El-Haleem, SA Zaki, AA Amara, GMS Aboelreesh "Genetic engineering of Schizosaccharomyces pombe to produce Bacterial Polyhydroxyalkanotes". J. Appl. Sci. Environ. Manage. vol. 11 pp. 1119-8362, 2007.

[59] DAM Abd-El-haleem, AA Amara, S Zaki, Abuelhamd A, Abuelreesh G "Biosynthesis of biodegradable polyhydroxyalkanotes biopolymers in genetically modified yeasts". Int. J. Environ. Sci. Tech. vol. 4 (4): pp. 513-520, 2007.

[60] A Steinbüchel and B Füchtenbusch "Bacterial and other biological systems for polyester production". Trends Biotechnol. vol. 16 pp. 419-427, 1998.

[61] Y Poirier, C Somerville, LA Schechtman, MM Satkowski and I Noda "Synthesis of highmolecular-weight poly $((R)-(\beta)$-3-hydroxybutyrate) in transgenic Arabidopsis thaliana plant cells". Int. J. Biol. Macromol. vol. 17 pp. 7-12, 1995.

[62] HE Valentin, DJ Rodriguez, DA Stone, SR Padgette, G Kishore and KJ Gruys "Metabolic engineering of Arabidopsis and Brassica for poly(3-hydroxybutyrate-co-3-hydroxyvalerate) copolymer production". Nat. Biotechnol. vol. 17 pp. 1011-1016, 1999.

[63] ME John and G Keller "Metabolic pathway engineering in cotton: biosynthesis of polyhydroxybutyrate in fiber cells". Proc. Natl. Acad. Sci. USA 93 pp. 12768-12773, 1996.

[64] Nakashita H, Arai Y, Yoshioka K, Fukui T, Doi Y, Usami R, Horikoshi K and Yamaguchi I "Production of biodegradable polyester by a transgenic tobacco". Biosci. Biotechnol. Biochem. vol. 63 pp. 870-874, 1999.

[65] S Slater, TA Mitsky, KL Houmiel, M Hao, SE Reiser, NB Taylor, M Tran, HE Valentin, DJ Rodriguez, DA Stone, SR Padgette, G Kishore and KJ Gruys "Metabolic engineering of Arabidopsis and Brassica for poly(3-hydroxybutyrate-co-3-hydroxyvalerate) copolymer production". Nat. Biotechnol. vol. 17 pp. 1011-1016, 1999.

[66] VV Mittendorf, EJ Robertson, RM Leech, N Kruger, A Steinbüchel and Y Poirier "Synthesis of medium-chain-length polyhydroxyalkanoates in Arabidopsis thaliana using intermediates of peroxisomal fatty acid oxidation". Proc. Natl. Acad. Sci., vol. 95 pp. 13397-13402, 1998.

[67] LA Petrasovits, MP Purnell, LK Nielsen and SM Brumbley "Production of polyhydroxybutyrate in sugarcane". Plant Biotechnol J. vol. 5(1) pp. 162-72, 2007.

[68] T. Lutke-Eversloh, J. Kawada, R. H. Marchessault and A. Steinbuchel, "Characterization of microbial polythioesters: physical properties of novel copolymers synthesized by Ralstonia eutropha", Biomacromolecules, vol. 3(1), pp. 159-166, 2002.

[69] T Lütke-Eversloh, K Bergander, H Luftmann and A Steinbüchel "Identification of a new class of biopolymer: bacterial synthesis of a sulfur-containing polymer with thioester linkages". Microbiology, vol. 147 pp. 11-19, 2001.

[70] M Liebergesell and A Steinbüchel "Cloning and nucleotide sequences of genes relevant for biosynthesis of poly(3-hydroxybutyric acid) in Chromatium vinosum strain D". Eur. J. Biochem., vol. 209 pp. 135-150, 1992.

[71] M Liebergesell, S Rahalkar. and A Steinbüchel "Analysis of the Thiocapsa pfennigii polyhydroxyalkanoate synthase: subcloning, molecular characterization and generation of hybrid synthases with the corresponding Chromatium vinosum enzyme". Appl. Microbiol. Biotechnol., vol. 54 pp. 186-194, 2000.

[72] TU Gerngross, KD Snell, OP Peoples, AJ Sinskey, E Csuhai, S Masamune and J Stubbe "Overexpression and purification of the soluble polyhydroxyalkanoate synthase from Alcaligenes eutrophus: evidence for it required posttranslational modification for catalytic activity". Biochemistry vol. 33 pp. 9311-9320, 1994.

[73] M Liebergesell, K Sonomoto, M Madkour, F Mayer and A Steinbüchel "Purification and characterization of the poly(hydroxyalkanoic acid) synthase from Chromatium vinosum and 
localization of the enzyme at the surface of poly(hydroxyalkanoic acid) granules". Eur. J. Biochem. vol. 226 pp. 71-80, 1994.

[74] R Jossek, R Reichelt and A Steinbüchel "In vitro biosynthesis of poly(3-hydroxybutyric acid) by using purified poly(hydroxyalkanoic acid) synthase of Chromatium vinosum". Appl. Microbiol. Biotechnol. vol. 49 pp. 258-266, 1998.

[75] A Timm and A Steinbüchel "Formation of polyesters consisting of medium chain length 3hydroxyalkanoic acids from gluconate by Pseudomonas aeruginosa and other fluorescent pseudomonads". Appl. Environ. Microbiol., vol. 56 pp. 3360-3367, 1990.

[76] Q Qi, BHA Rehm and A Steinbüchel "Synthesis of poly(3-hydroxyalkanoates) in Escherichia coli expressing the PHA synthase gene phaC2 from Pseudomonas aeruginosa": comparison of PhaC1 and PhaC2. FEMS Microbiol. Lett. vol. 157 pp. 155$162,1997$.

[77] Q Qi, A Steinbüchel and BHA Rehm "Metabolic routing towards polyhydroxyalkanoic acid synthesis in recombinant Escherichia coli ( $\mathrm{fadR}$ ): inhibition of fatty acid $\beta$-oxidation by acrylic acid". FEMS Microbiol. Lett. vol. 167 pp. 89-94, 1998.

[78] BHA Rehm, N Krüger and A Steinbüchel "A new metabolic link between fatty acid de novo synthesis and polyhydroxyalkanoic acid synthesis". J. Biol. Chem. vol. 273 pp. 24044-24051, 1998.

[79] BHA Rehm and A Steinbüchel "PHA synthases-the key enzymes of PHA synthesis. In "Biopolymers", A Steinbüchel,. and Y Doi,. (Eds.), Wiley-VCH, Heidelberg, Germany, pp. 173-215, 2001.

[80] S Fiedler, A Steinbüchel and BHA Rehm "PhaG-mediated synthesis of poly(3hydroxyalkanoates) consisting of medium-chain-length constituents from nonrelated carbon sources in recombinant Pseudomonas fragi". Appl. Environ. Microbiol. vol. 66 pp. 21172124, 2000.

[81] N Hoffmann, A Steinbüchel and BHA Rehm "The Pseudomonas aeruginosa phaG gene product is involved in the synthesis of polyhydroxyalkanoic acid consisting of mediumchain-length constituents from non-related carbon sources". FEMS Microbiol. Lett., vol. 184 pp. 253-259, 2000a.

[82] N Hoffmann, A Steinbüchel and BHA Rehm "Homologous functional expression of cryptic phaG from Pseudomonas oleovorans establishes the transacylase-mediated polyhydroxyalkanoate biosynthetic pathway". Appl. Microbiol. Biotechnol., vol. 54 pp. 665-670, 2000.

[83] BHA Rehm, Q Qi, BrB Beermann, HJ Hinz and A Steinbüchel "Matrix-assisted in vivo refolding of Pseudomonas aeruginosa class II polyhydroxyalkanoate synthase from inclusion bodies produced in recombinant Escherichia coli". Biochem. J. vol. 358 pp. 263268, 2001b.

[84] Q Qi, , A Steinbüchel and BHA Rehm "In vitro synthesis of poly(3-hydroxydecanoate): purification and enzymatic characterization of type II polyhydroxyalkanoate synthases $\mathrm{PhaC} 1$ and PhaC2 from Pseudomonas aeruginosa". Appl. Microbiol. Biotechnol. vol. 54 pp. 37-43, 2000.

[85] Y Jia, TJ Kappock, T Frick, AJ Sinskey and J Stubbe "Lipases provide a new mechanistic model for polyhydroxybutyrate (PHB) synthases: characterization of the functional residues in Chromatium vinosum PHB synthase". Biochemistry, vol. 39 pp. 3927-3936, 2000.

[86] BHA Rehm, RV Antonio, P Spiekermann, AA Amara and A Steinbüchel "Molecular characterization of the poly(3-hydroxybutyrate) (PHB) synthase from Ralstonia eutropha: in vitro evolution, site-specific mutagenesis and development of a PHB synthase protein model". Biochim. Biophys. Acta vol. 1594 pp. 178-190, 2002.

[87] AA Amara and BHA Rehm "Replacement of the catalytic nucleophile cysteine-296 by serine in class II polyhydroxyalkanoate synthase from Pseudomonas aeruginosa-mediated synthesis of a new polyester: identification of catalytic residues". Biochem. J. vol. 1; 374(Pt 2): pp. 413-21, 2003.

[88] U Müh, K Snell, E Troyano, J Wodzinska, AJ Sinskey and J Stubbe "In: 'Biochemical principles and mechanism of biosynthesis and biodegradation of polymers", an international symposium, Abstract book, Lecture 6, Münster, Germany. 1998. 
[89] A Hoppensack, BHA Rehm and A Steinbüchel "Analysis of 4-phosphopantetheinylation of polyhydroxybutyrate synthase from Ralstonia eutropha: generation of $\beta$-alanine auxotrophic Tn5 mutants and cloning of the panD gene region". J. Bacteriol. vol. $181 \mathrm{pp}$. 1429-1435, 1999.

[90] GJ McCool and MC Cannon "PhaC and PhaR are required for polyhydroxyalkanoic acid synthase activity in Bacillus megaterium". J. Bacteriol. vol. 183 pp. 4235-4243, 2001.

[91] T Saito, K Suzuki, J Yamamoto, T Fukui, K Miwa, K Tomita, S Nakauishi, S Odani, JI Suzuki and K Ishikawa "Cloning, nucleotide sequence, and expression in Escherichia coli of the gene for poly(3-hydroxybutyrate) depolymerase from Alcaligenes faecalis". J. Bacteriol. vol. 171 pp. 184-189, 1989.

[92] B Klingbei, RM Kroppenstedt, and D Jendrossek, "Taxonomic identification of Streptomyces exfoliates K10 and characterization of its poly(3-hydroxybutyrate) depolymerase gene". FEMS Microbiol. Lett., vol. 142(2-3) pp. 215-221, 1996.

[93] A Schirmer, Matz C and Jendrossek D "Substrate specificities of PHA-degrading bactria and active site studies on the extracellular poly(3-hydroxyactonoic acid) $\mathrm{P}(3 \mathrm{HO})$ ] depolymerise of Pseudomonas fluorescens GK13 biovar V". Appl. Environ. Microbiol., vol. 59 pp. 1220-1227, 1995.

[94] H Saegusa, M Shiraki, C Kanai and T Saito "Cloning of an intracellular Poly[D(-)-3Hydroxybutyrate] depolymerase gene from Ralstonia eutropha H16 and characterization of the gene product". J. Bacteriol., vol. 183 pp. 94-100, 2001.

[95] H Saegusa, M Shiraki and T Saito "Cloning of an intracellular D(-)-3-hydroxybutyrateoligomer hydrolase gene from Ralstonia eutropha $\mathrm{H} 16$ and identification of the active site serine residue by site-directed mutagenesis". J. Biosci. Bioeng., vol. 94 pp. 106-112, 2002.

[96] T Kobayashi, M Shiraki, T Abe, A Sugiyama and T Saito "Purification and properties of an intracellular 3-hydroxybutyrate-oligomer hydrolase (PhaZ2) in Ralstonia eutropha H16 and its identification as a novel intracellular poly(3-hydroxybutyrate) depolymerase". J. Bacteriol., vol. 185 pp. 3485-3490, 2003.

[97] GM York, J Stubbe and AJ Sinskey "The Ralstonia eutropha PhaR protein couples synthesis of the PhaP phasin to the presence of polyhydroxybutyrate in cells and promotes polyhydroxybutyrate production". J. Bacteriol. vol. 184 pp. 59-66, 2002.

[98] TM Scherer, Fuller, S Goodwin and RW Lenz "Enzymatic hydrolysis of oligomeric models of poly- RC 3-hydroxybutyrate". Biomacromolecules , vol. 1 pp. 577-583, 2000.

[99] P Gruchulski, F Bouthillier, RJ Kazlauskas, AN Serreqi, JD Schrag, E Ziomek and M Cygler "Analogs of reaction intermediates identify a unique substrate binding site in Candida rugosa lipase". Biochemistry, vol. 33 pp. 3494-3500, 1994.

[100] KE Jaeger A Steinbuchel and D Jendrossek "Substrate specificities of bacterial polyhydroxyalkanoate depolymerases and lipases: bacterial lipases hydrolyze poly(omegahydroxyalkanoates) ". Appl. Environ. Microbiol., vol. 61(8) pp. 3113-3118, 1995.

[101] SR Salem, HMA Soliman. and AA. Amara "Polymer-Strips a method for characterization of PHB depolymerase activity in Alcaligenes xylosoxidans subsp. denitrificans and Citrobacter sp". New J. of Egyptian Microbiology. vol. 16 pp. 191-200, 2007.

[102] AA Amara and RS Salem "Characterization of PHA depolymerase in phenol degrading bacteria". International J. of Biotechnol. Biochemi. vol. 3: pp. 69-81, 2007

[103] J Ihssen, D Magnani, L Tho $\square$ ny-Meyer, Q Ren "Use of Extracellular Medium Chain Length Polyhydroxyalkanoate Depolymerase for Targeted Binding of Proteins to Artificial Poly[(3-hydroxyoctanoate)-co-(3-hydroxyhexanoate)] Granules". Biomacromolecules. vol.10, Issue: 7, pp. 1854-1864, 2009.

[104] S Taguchi, A Maehara, K Takase, M Nakahara, H Nakamura and Y Doi "Analysis of mutational effects of a polyhydroxybutyrate (PHB) polymerase on bacterial PHB accumulation using an in vivo assay system". FEMS Microbiol. Lett., vol. 198 pp. 65-71, 2001.

[105] S Taguchi, H Nakamura, T Hiraishi, I Yamato and Y Doi "In vitro evolution of a polyhydroxybutyrate synthase by intragenic suppression-type mutagenesis". J. Biochem., (Tokyo), vol. 131(6) pp. 801-806, 2002. 
[106] F Hu, Y Cao, F Xiao, J Zhang, H Li "Site-directed mutagenesis of Aeromonas hydrophila enoyl coenzyme A hydratase enhancing 3-hydroxyhexanoate fractions of poly(3hydroxybutyrate-co-3-hydroxyhexanoate) ". Curr Microbiol. vol. 55(1) pp. 20-24, 2007.

[107] K Matsumoto, K Takase, Y Yamamoto, Y Doi and S Taguchi "Chimeric enzyme composed of polyhydroxyalkanoate (PHA) synthases from $C$. necator and Aeromonas caviae enhances production of PHAs in recombinant Escherichia coli". Biomacromolecules. vol. 10(4) pp. 682-5, 2009.

[108] N Hoffmann, AA Amara, BrB Beermann, Q Qi, HJ Hinz and BHA Rehm "Biochemical characterization of the Pseudomonas putida 3-hydroxyacyl ACP:CoA transacylase which diverts intermediates of fatty acid de novo biosynthesis". J. Biol. Chem. vol. 277 pp. 4292642936, 2002. 